\title{
Field Evaluation of Hydrologic and Water Quality Benefits of Perforated Paving Block Structure (P2BS)
}

\author{
Suripin S*, Sachro Sri Sangkawati, Atmojo Pranoto Samto, Edhisono Sutarto, Kurniani \\ Dwi, Budieny Hery \\ Civil Engineering Department, Diponegoro University, Semarang Indonesia
}

\begin{abstract}
This paper discusses the use of perforated paving block structure (P2BS) as a pavement structure on the parking lot. Model of P2BS was developed in the field to analyze its capacity in reducing runoff and improving surface runoff quality. The depth and intensity of the rainfall is regulated with a rainfall simulator. The rate of native soil infiltration (natural) was tested with ring infiltrometer. The model's ability to reduce peak discharge and runoff volume, delay time, as well as improve quality of surface runoff was observed. The results show that proposed P2BS are able to significantly reduce runoff volume and peak discharge, delay start runoff and peak discharge time. It is also able to remove pollutants, especially TSS.
\end{abstract}

Keywords. delay start runoff; perforated paving block; pollutants, rainfall simulator

\section{Introduction}

Urbanization and urban development bring an increase in the impermeable surface area, such as roads, sidewalks, parking lots, and so on. They all result in surface runoff and additional pollutants during rainfall, resulting in increased flood discharge, and pollution of water bodies [1-4]. Increased runoff requires greater urban drainage infrastructure. Increased runoff also means reducing groundwater recharge, and reducing the availability of clean water for many communities that still rely on ground water.

The runoff from traffic infrastructure, such as roads, parking lots, and pedestrians carries various pollutants including organic matter, nutrients, heavy metals, oils and suspended solids, which have previously been deposited on their surfaces. The majority of pollution originates from traffic emissions, soil erosion, and decomposing litter of leaves from shade plants [4]. The pollutants which are usually carried away by storm-water runoff of pavements are: (a) solid particulates, like dust and litter transferred by the traffic, (b) heavy metals, like lead, zinc, iron, copper, cadmium, chromium, nickel, manganese, barium, cesium and antimony, and (c) Chlorides [5]. They are deposited on the pavement surfaces. During rainfall events, these pollutants are washed out by surface runoff along with atmospheric pollutants. 
These pollutants pose a risk to the urban watercourse and groundwater quality, if they remain untreated $[1,3,6-8,9]$.

Conscious of the negative impacts of the impermeable surface, in recent years there has been a paradigm shift in the drainage system in treating rainwater. The conventional drainage system concept drained rainwater as quickly as possible, shifting to a sustainable drainage system with the concept of managing rainwater. In general, rainwater management can be done by storing it, either stored above the land surface in the form of embung, reservoir and the like or infiltrated into the ground as ground water.

The development of reservoirs in urban areas is difficult and expensive due to limited land. The infiltration system is a rational alternative. One of the most potent rainwater infiltration systems in urban areas is the paving block pavement, commonly known as perforated paving block structure (P2BS). It is suitable for a wide variety of light transportation infrastructures, such as motorcycle lanes, parking lots, sidewalks, and pedestrians [10]. P2BS have a lot of potential benefits such as reduction of runoff, recharging of groundwater, and prevention of ground water pollution [11]. P2BS be able to reduce peak flow and prolong discharging times through infiltration and detention in underground reservoir [12, 13, 9]. Harmful pollutants carried out by surface runoff such as hydrocarbons and heavy metals have the potential to endanger groundwater resources when they are not removed during infiltration $[14,15]$.

The objectives of this study are to estimate the water storage capacity of perforated paving block structure structures, which can be used as a parameter for output calculations in the design of drainage channels. Hydrologic responses of the pavement, such as runoff volume, storage capacity, peak discharge, and effect of delay were evaluated through a rainfall simulation experiment. Their capability to remove pollutants was also analyzed.

\section{The Experimental Site, Materials, and Equipment}

The P2BS model was developed in the parking lot of the Civil Engineering Department of Diponegoro University, Semarang Indonesia. The existing conventional paving block pavement cannot manage storm water, so when there is heavy rain there is always a inundation on the surface of the pavement. Inundation may last more than 1 day ( 24 hours). Paving blocks used in the form of cubes with the size of $21 \mathrm{~cm}$ long, $10.5 \mathrm{~cm}$ wide, and 6 $\mathrm{cm}$ thick. The pavement paving block structure is composed of a layer of paving block laid down on a $5 \mathrm{~cm}$ thick layer of sand that is spread directly over a compacted clay base (Fig. 1). As result the capacity in storing water as well as the infiltration capacity is low.

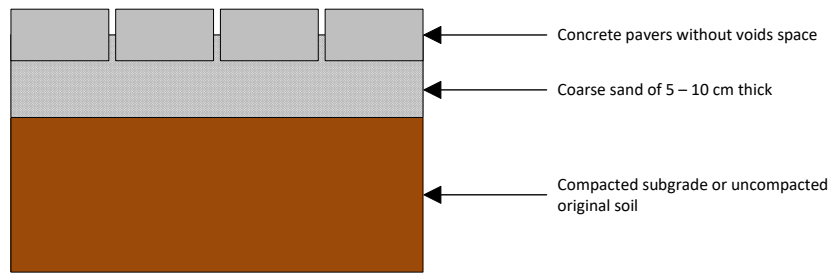

Fig. 1. Structure of Conventional Existing Paving Block without Storage Base

The perforated paving block structure (P2BS) model is constructed in the form of model with a length of $240 \mathrm{~cm}$ and a width of $150 \mathrm{~cm}$ (Fig. 2). The fundamental difference between conventional paving block pavement and P2BS is the presence of voids in perforated pavement, including the pavement surface, which reduces imperviousness and allows storm water to infiltrate into and through the pavement [16]. The general structure of P2BS consists 
of several layers, covering a surface layer of permeable paving concrete, arranged manually on a layer of sand, and a layer of gravel. The characteristics and thickness of each material depends on the size of the discharge to be managed [17]. General structure of perforated paving block structure is shown in Fig. 3 [18].

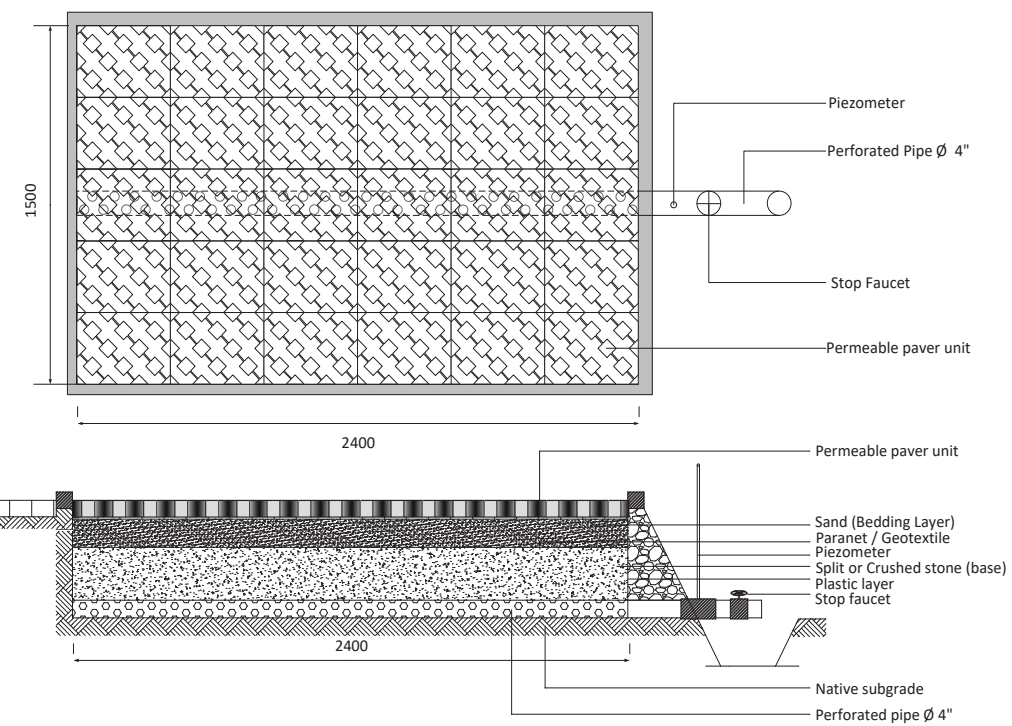

Fig. 2. Perforated paving block structure (P2BS) Model

Perforated paving block type, with size $40 \mathrm{~cm}$ long, $30 \mathrm{~cm}$ wide, and $8 \mathrm{~cm}$ thick was used (Fig. 3). The ratio between the perforated hole area to the total surface area of paving is approximately $40 \%$. Open graded material consists of 2 types, coarse sand and crushed stone. Open graded bedding coarse that consists of coarse sand with porosity $25 \%$ is used for the base of installation of concrete pavers. While open graded base reservoir serves as a water reservoir consisting of crushed stone ranges in size from 19 to $63 \mathrm{~mm}$ and porosity ranges from $39 \%$. To reduce fine material flowing and filling the pores of the rougher material, geotextile was spread between the two types of open graded material. Permeable block pavers were used on the top surface with the slope of $1 \%$. Perforated pipe was used in the sub-grade layer to capture the infiltrate storm water and move it to the drainage system. This P2BS was designed to capture rainfalls ranging in intensity from about 225 to $250 \mathrm{~mm} / \mathrm{h}$ as occurs with various storm events. Fig. 3 shows the P2BS model used in this study.
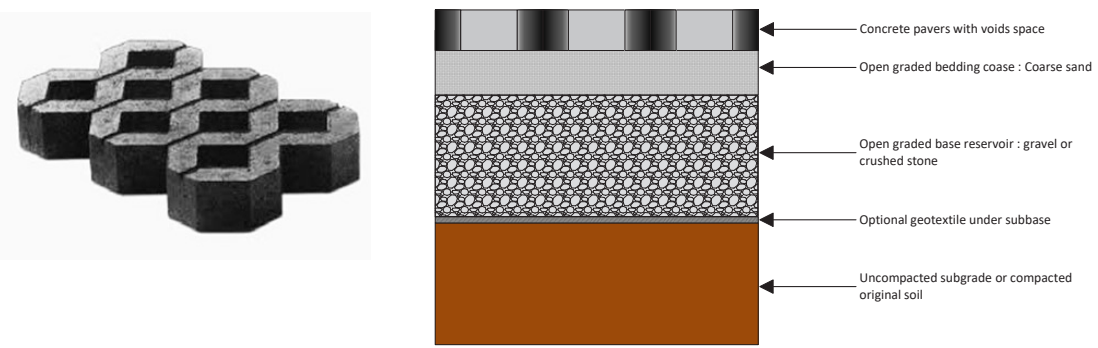

Fig 3. Perforated paving block type, and the general structure of perforated paving block structure (P2BS) 


\section{Results and Discussion}

Perforated paving blocks (P2BS) can be designed with full or partial exfiltration of the soil sub grade. A design for full exfiltration means the water infiltrates directly into the base and infiltrates to the soil. This is the most common application. Overflows are managed via perimeter drainage to swales, bio-retention areas or storm sewer inlets. Partial exfiltration does not rely completely on exfiltration of the base into the soil to dispose of all the captured runoff. Some of the water may infiltrate into the soil while the remainder is drained by perforated pipes. Excess water is drained from the base by perforated pipes to drainage system or a stream [18].

Measurements were made to the depth and duration of rainfall, the water level in the P2BS and the outflow of the perforated pipe for every time interval. The rainfall depths simulated for this study were based on design rainfall of 5 year return period for Semarang City area. Taking into account the effects of climate change on rainfall characteristics, the design rainfall was $120 \mathrm{~mm}$ [19]. Rain duration of 25-30 minutes were applied, the intensities of rain were then become $250-225 \mathrm{~mm} / \mathrm{h}$. Soil permeability was obtained both from laboratory analysis and field infiltration test. Laboratory analyses found that the soil permeability is $17.64 \mathrm{~mm}$ /hour, while infiltration test resulted slightly lower, as shown in Figure 5. Similar results were obtained in previous studies with adjacent sites [20].

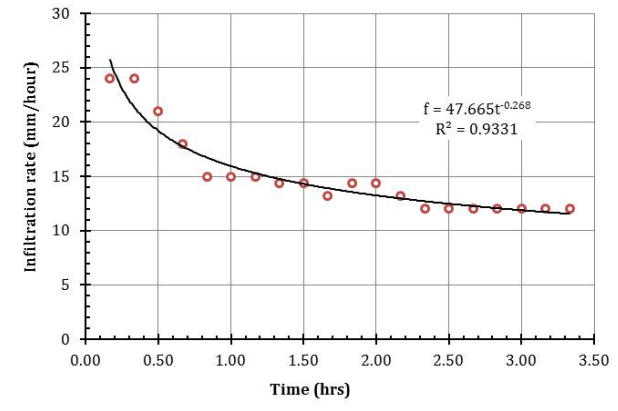

Fig. 4. Infiltration rate based on the field measurement using infiltrometer

\subsection{Effect to Runoff Characteristics}

The effects of P2BS to runoff characteristics were evaluated by partial exfiltration type. The amount of rain-water, the rainfall intensity, and outflow were recorded. Start delay and peak flow time, as well as peak discharge were evaluated for the experiment. Start delay is defined as the start time of the rainfall until the outflow occurs at the perforated pipe outlet of the P2BS. While peak flow time is defined as the lag time between the start of the rain until the peak of the flow is reached. The experiments were performed twice with rain intensities of 225 and $250 \mathrm{~mm} / \mathrm{h}$ for a given time at which a constant discharge was reached. This is the peak discharge. Observation of discharge was done from the beginning of the rain until the discharge return to zero. Since the pavement area is $150 \mathrm{~cm} \mathrm{x} 240 \mathrm{~cm}=3.6 \mathrm{~m}^{2}$, the rain intensity of 225 and $250 \mathrm{~mm} / \mathrm{h}$ each equals 0.225 liters / s and 0.250 liters/s consecutively. Fig. 5 shows the experimental hydrograph with two different rain intensities. Both give almost the same results, where start delay of 13 minutes and peak discharge time 20 minutes.

Theoretically, peak flow time is defined as the sum of the overland sheet flow travel time $\left(\mathrm{t}_{0}\right)$ and travel time in the channel $\left(\mathrm{t}_{\mathrm{ch}}\right)$ of the most remote point. In this case, there was only overland sheet flow, as the outflow was measured directly in the outlet of PCI. The overland sheet flow travel can be estimated used Friend's formula as follows [21]: 


$$
t_{o}=\frac{107 * n * L^{\frac{1}{3}}}{\sqrt{S}}
$$

where: $\mathrm{n}$ is Manning's roughness value for the concrete block surface; $\mathrm{S}$ is the slope of the overland surface (\%); $t_{0}$ is overland sheet flow travel time (min); and $\mathrm{L}$ is the flow path length of the overland sheet $(\mathrm{m})$.
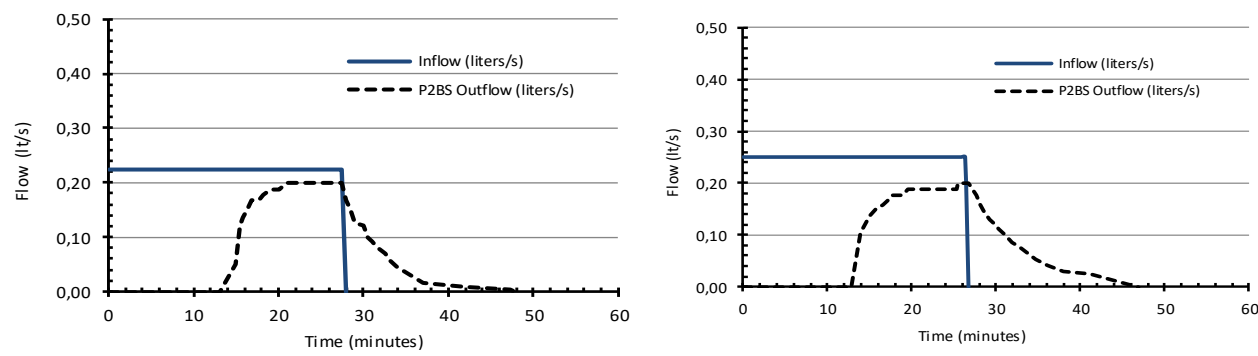

Fig. 5. Hydrographs for rainfall intensity $225 \mathrm{~mm} / \mathrm{h}$ (left) and $250 \mathrm{~mm} / \mathrm{h}$ (right)

The peak flow time for the conventional paving block in this case would be 5 minutes, compared to 20 minutes for P2BS, which is shows significant benefits. The similar results showed by [22]. They found that the permeable pavement peak flow was between $5 \sim 10$ minutes, compared to $2 \sim 3$ minutes for conventional pavement.

\subsection{Storage Capacity}

The capacity of P2BS depends on material characteristics, especially its porosity. Porosity for open graded bedding coarse and open graded base reservoir layer are $25 \%$ and $39 \%$ respectively. Water balance model components are defined for the rainfall amount, surface runoff, P2BS storage and drainage channel flow, and formulated as follows:

$$
\begin{aligned}
& V_{w}=h_{p} A_{p} V_{r}=P A_{p}-Q_{r_{o}} \Delta t-f \Delta t A_{p}-Q_{o} \Delta t \\
& \left(\frac{V_{w}}{A_{p}}\right)=h_{p} V_{r}=P-\left(\frac{Q_{r_{o}}}{A_{p}}+f+\frac{Q_{o}}{A_{p}}\right) \Delta t
\end{aligned}
$$

where: $h_{p}$ : the base depth, $m ; A_{p}$ : surface area of permeable pavement, $\mathrm{m}^{2} ; \mathrm{V}_{\mathrm{r}}$ : void ratio of pavement filler material (base); $\mathrm{V}_{\mathrm{w}}$ is the water volume in $\mathrm{P} 2 \mathrm{BS}, \mathrm{m}^{3} ; \mathrm{Q}_{\mathrm{o}}$ : outflow from the pavement through perforated pipe, $\mathrm{m}^{3} / \mathrm{s} ; \mathrm{P}$ : rainfall depth, $\mathrm{m}$; Q Q : surface runoff, $\mathrm{m}^{3} / \mathrm{s}$; f: infiltration rate of native soil (base soil), $\mathrm{m} /$ hour; $\Delta \mathrm{t}$ : time interval of measurement, seconds.

Table 1. Characteristics of the Materials

\begin{tabular}{lccc}
\hline \multicolumn{1}{c}{ Characteristics } & $\begin{array}{c}\text { Open graded base } \\
\text { reservoir }\end{array}$ & $\begin{array}{c}\text { Open graded } \\
\text { bedding coarse }\end{array}$ & Grade paver \\
\hline Thickness $(\mathrm{mm})$ & 300 & 120 & 80 \\
Porosity $(\%)$ & 39 & 25 & $\mathrm{n} / \mathrm{a}$ \\
\hline
\end{tabular}

Two different rainfall intensities were used in the experiment, ea.: $90 \mathrm{~mm} / \mathrm{h}$ during 2 hours and $140 \mathrm{~mm} / \mathrm{h}$ during 2 and half hours. Rainwater that has filled the open graded materials and has been saturated was monitored through a piezometer mounted on a perforated pipe near the outlet. The water level in the P2BS is considered equal to the water level in the piezometer, so the capacity could be calculated. This value is called the observed storage. The predicted storage is obtained by entering the P2BS model data and the material 
characteristics into equation (3), with various time intervals for constant rainfall intensity. During the experiment, there was no surface runoff. Since the experiment used full exfiltration type, there was also no outflow. So that the volume of water stored in the open grade reservoir depends only on rainfall and infiltration.

By converting all units into the volume per unit area $\left(1 / \mathrm{m}^{2}\right)$, both observed and predicted capacities could be correlated. The result of plotting the data shows the points scattered balanced around the 1: 1 line, and yields a good correlation between the measured volume and the predicted volume, with the value $r^{2}$ close to one (Fig. 6).

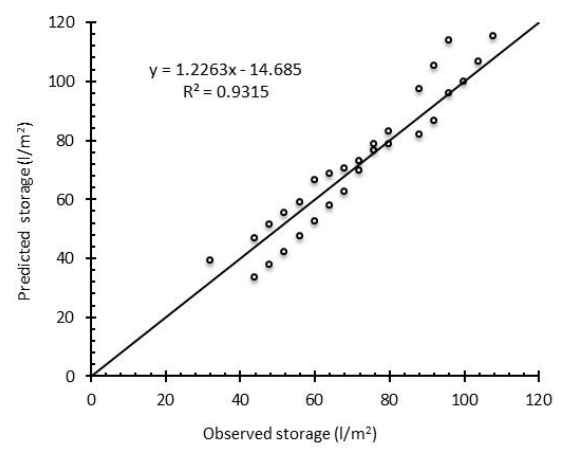

Fig. 6. Regression of predicted and observed storage of simulated P2BS

The experimental simulation result demonstrates that rainwater management facilities can be easily designed using P2BS full exfiltration type. Dependent variables are rainfall, natural soil permeability, and P2BS filler material characteristics. It should be noted that the perforated paving block used as a pavement surface layer must be able to pass the water and air freely.

\subsection{Water Quality}

The capacity of P2BS in removing pollutants was analyzed based on the water quality before and after passing P2BS. Water samples of rain water, surface runoff flowing into and out of P2BS were carried out during height storm events. The pollutants usually found in the surface runoff from parking lot are heavy metals, like lead, cadmium, chromium, aluminum, zinc, cuprum, mercury, and nickel. Other pollutants are solid particulates, like dust and litter. These kinds of pollutants in the water are called total suspended solids (TSS).

The collected data show quite low concentrations of metal elements in storm water runoff except for TSS, Zinc, and Cuprum. The quality of rainwater in the study site is still good, where the concentration of all pollutants elements is very low (Table 2). The general low concentrations of metal elements in storm water runoff are probably due to the fact that this experimental area (parking lot) is low traffics, and experiments were carried out in the mid of rainy season.

Table 2. Quality characteristics of the collected storm events

\begin{tabular}{|c|l|l|l|c|c|c|c|c|}
\hline \multirow{2}{*}{ No. } & \multirow{2}{*}{ Name } & \multirow{2}{*}{ Notation } & \multirow{2}{*}{ Unit } & \multirow{2}{*}{ Rainwater } & \multicolumn{2}{|c|}{ Inflow to P2BS } & \multicolumn{2}{|c|}{$\begin{array}{c}\text { Outflow from } \\
\text { P2BS }\end{array}$} \\
\cline { 5 - 9 } & & & & & SI-1 & SI-2 & SO-1 & SO-2 \\
\hline 1 & TDS & TDS & $\mathrm{mg} / 1$ & 15 & 228 & 54 & 344 & 88.6 \\
\hline 2 & Lead & $\mathrm{Pb}$ & $\mathrm{mg} / 1$ & $<0.010$ & $<0.010$ & $<0.010$ & $<0.010$ & $<0.010$ \\
\hline 3 & Cadmium & $\mathrm{Cd}$ & $\mathrm{mg} / 1$ & $<0.003$ & $<0.003$ & $<0.003$ & $<0.003$ & $<0.003$ \\
\hline
\end{tabular}




\begin{tabular}{|c|l|c|c|c|c|c|c|c|}
4 & Chromium & $\mathrm{Cr}$ & $\mathrm{mg} / 1$ & $<0.016$ & $<0.016$ & $<0.016$ & $<0.016$ & $<0.016$ \\
\hline 5 & Aluminum & $\mathrm{Al}$ & $\mathrm{mg} / 1$ & $<0.160$ & $<0.160$ & $<0.160$ & $<0.160$ & $<0.160$ \\
\hline 6 & Zinc & $\mathrm{Zn}$ & $\mathrm{mg} / \mathrm{l}$ & 0.009 & 0.034 & 0.136 & 0.083 & 0.083 \\
\hline 7 & Cuprum & $\mathrm{Cu}$ & $\mathrm{mg} / 1$ & $<0.120$ & 0.030 & 0.322 & 0.033 & 0.118 \\
\hline 8 & Mercury & $\mathrm{Hg}$ & $\mathrm{mg} / 1$ & $<0.004$ & $<0.004$ & $<0.004$ & $<0.004$ & $<0.004$ \\
\hline 9 & Nickel & $\mathrm{Ni}$ & $\mathrm{mg} / 1$ & $<0.001$ & $<0.001$ & $<0.001$ & $<0.001$ & $<0.001$ \\
\hline 10 & Sulfur & $\mathrm{H}_{2} \mathrm{~S}$ & $\mathrm{mg} / \mathrm{l}$ & $<0.008$ & $<0.008$ & $<0.008$ & $<0.008$ & $<0.008$ \\
\hline
\end{tabular}

\section{Conclusion and Recommendation}

Based on the experimental results in this paper, the storage water capacity of perforated paving block structure (P2BS) structures can be estimated based on the materials properties of porosity. This result can be used to design a permeable pavement structure. The effects P2BS to hydrologic responses of the pavement, such as delay effects, peak discharge, and storage capacity, could be evaluated through a rainfall simulation experiment. The start delay for this process ranged from 12 to 13 minutes for the rainfall intensity 225 to $250 \mathrm{~mm} / \mathrm{h}$, and the prolong the peak discharge time surface runoff from 5 minutes for conventional paving block pavement to 20 minutes for P2BS. It was also proved capable of capturing pollutants surface runoff, especially TSS.

\section{Acknowledgments}

Thank you delivered to the Institute for Research and Community Services (LPPM) of Diponegoro University for the financial support of this research. The authors thank also to Legimin and Daryono for assistance in the field experiments. Further thanks are extended to Felix Hariyanto for assistance in preparing the drawing.

\section{References}

1. Muschack W. (1990). The Science of the Total Environment, 93, 419-431.

2. Ball JE., Jenks R. and Ausborg D. (1998). The Science of the Total Env., 209, 243-254

3. Vaze J. and Chiew FHS. (2002). Urban Water, 4, 379-389

4. Scholz M. (2010). Wetland System-Storm Water Management Control. Springer Verlag: Berlin, Germany.

5. Yannopoulos, Basbas, and Giannopoulou (2013). Global NEST J., 15 (1), 85-92.

6. Tong S. (1990). J. of Env. Manag, 14 (1), 107-113

7. Deletic A.B. and Mahsimivic C.T. (1998). J. of Env. Eng, 124 (9), 869-879

8. Sansalone J. J., Koran J.M., Smithson J.A. and Buchberger S.G. (1998). J. of Env. Eng., 124 (5), 427-440

9. Pagotto C, Legret M, Le Cloirec P. (2000). Water Research, 34 (18): 46-54.

10. Scholz M, and Grabowiecki P. (2007). Building and Environmen, 42 (2007) 3830-3836

11. Pratt CJ, Newman AP, Bond PC. (1999). Water Science and Technology, 39 (2), 109130.

12. Booth DB, Leavitt J. (1999). American Planning Ass. J., 65(3), 314-25

13. Abbot CL, Comino-Mateos L. (2003). J. of the Chartered Inst. of Water and Env.Manag, 17 (3):187-90.

14. Brattebo BO, Booth DB. (2003). Water Research 2003; 37 (26), 4369-4376. 
15. Dierkes C, Kuhlman L, Kandasamy J, Angelis G. (2002). Pollution retention capability and maintenance of permeable pavements. In: Strecker EW, editor. Proceedings of the ninth international conference on urban drainage, Portland, USA, 8-13 September 2002.

16. Ndon UJ. (2017). J Civil and Environ Eng. 7: 288. DOI: 10.4172/2165-784X.1000288

17. Sample DJ. (2013). Best Management Practice Fact Sheet 7: Permeable Pavement, Publication 426-126. Virginia State University.

18. Smith, D.R. (2006). Maryland Stormwater Manual, $3^{\text {rd }}$ ed. State of Maryland, Department of the Environment, Baltimore, Maryland, 2006.

19. Suripin dan Kurniani D. (2016). J. Media Komunikasi Teknik Sipil, 22 (2), Des. 2016, 119-128.

20. Suripin, Kurniani D., dan Budieny H. (2010). J. of Mathematics and Technology, ISSN: 2078-0257, 5, December, 2010, 57-60.

21. Park D, Sandoval N, Lin W, Kim H, and Cho Y. (2013). KSCE J. of Civil Engineering, 18 (2) March 2014, 514-520.

22. Pratt, C. J., Mantle, J. D. G., and Schofield, P. A. (1989). Water Science \& Technology, $21(8-9), 769-778$ 